\title{
Continous Quality Improvement Dalam TQM
}

\author{
Oleh : Moh. Hasim Asy’ari \\ NIM : 1630500088 \\ E-mail : Hasimgoki121@gmail.com
}

\begin{abstract}
ABSTRAK
Dalam TQM. Continous Quality Improvement atau sering di sebut juga dengan perbaikan mutu berkesinambungan merupakan salah satu unsur yang paling fundamental. Oleh karena itu, penting bagi kita untuk mengetahui apa saja hal-hal yang harus di perhatikan sebelum melakukan perbaikan dalam perusahaan/organisasi di antaranya untuk apa perbaikan itu d lakukan, apa saja prinsip perbaikan berkesinambungan, apa saja konsep penting yang terkandung dalam perbaikan berkesinambungan. Di sini kami mengambil dari sudut pandang orang jepang yaitu teori kaizen.
\end{abstract}

Kata Kunci : Perbaikan Berkesinambungan, teori kaizen.

\section{PENDAHULUAN}

\section{Latar Belakang}

Setelah perang dunia ke 2, fenomena ekonomi di jepang mengalami pertumbuhan untuk menumbuhkan motivasi dalam membangun kembali dari sisa-sisa perang dan Amerika menugaskan salah satu ahli survey yang bernama Dr. W. Edward Deming untuk ikut membantu dalam membangun kembali ekonomi jepang sehingga konsep deming mulai di terapkan oleh perusahaan jepang pada tahun 1970-an dan anehnya setelah perusaahan jepang sukses dengan konsep ini Amerika mulai tertarik untuk menerapkan konsep deming tersebut.

Namun konsep deming ini di jepang lebih di kenal dengan sebutan kaizen dan mulai di perkenal luaskan oleh Masaaki Imai dalam bukunya yang berjudul "Kaizen : the key to Japan's competitive success" pada tahun 1986. Europe Japan Centre menyimpulkan dan mengungkapkan "Kaizen menjelaskan pada kita bahwasannya hanya dengan secara terus menerus bisa membuat beratus-ratus ribu peningkatan kecil, maka besar kemungkinan untuk memproduksi barang dan jasa yang memiliki mutu terpercaya sehingga para pelanggan dapat di puaskan. Cara yang paling gampang untuk mencapai tujuan tersebut adalah dengan keikutsertaan, motivasi dan melakukan peningkatan terus menerus dari semua para pekerja dalam organisasi. Keikutsertaan pekerja tergantung pada perjanjian manajemen senior, dan 
strategi yang jelas. Karena konsep kaizen ini bukanlah konsep yang beroriantasi pada proses yang instan namun lebih mengandalkan pada proses dengan berkelanjutan”. (Cane, 1998:265)

Jepang memang unggul dalam hal persaingan. Karena mengandalkan kemampuannya dalam bidang produksi yaitu dengan menyingkirkan pemborosan pada produksi dan biaya dan berusaha menghindari dari segala kesulitan. Lain halnya dengan Amerika serikat yang selalu mengalami kesulitan dalam menghemat SDA yang sangat melimpah jika dibandingkan dengan negara jepang sehingga perbaikan terus menerus (just in time) tidak berhasil bagi manajemen Amerika namun lebih mengarah ke just in case.

\section{PEMBAHASAN}

\section{Pengertian Kaizen}

Kaizen merupakan filosofi jepang yang memfokuskan pada proses berkelanjutan dalam suatu perusahaan bisnis. Kaizen terdiri dari dua kata yaitu kai berarti perbaikan dan zen yang berarti baik. Dalam istilah lain, kaizen disebut juga sebagai continous improvement. Jadi, kaizen adalah usaha berkelanjutan untuk melakukan perbaikan suatu proses yang ada pada sebuah perusahaan bisnis.

Konsep ini mencontohkan bahwa hidup kita yang mana mulai dari aktifitas dan gaya hidup kita harus berusaha untuk melakukan perbaikan berkelanjutan, meskipun perbaikan tesebut di lakukan secara sedikit-sedikit dan bertahap.

\section{Sasaran Kaizen}

Sasaran akhir dari konsep kaizen adalah tercapainya kualitas, biaya, dan distribusi. Namun, pada praktiknya kaizen kualitas sebagai prioritas tertinggi. Kaizen menjelaskan bahwa sebuah perusahaan tidak akan mampu bersiang jika kualitas dan pelayanannya tidak memadai. Oleh karena itu, komitmen manajemn terhadap kualitas sangat di junjung tinggi. Kualitas yang di maksud adalah bukan hanya kualitas produknya tetapi juga kualitas dari setiap proses dalam menghasilkan produknya.

\section{Dasar Kaizen}

Dasar dari kaizen adalah sebagai berikut :

\section{Berorientasi pada proses dan hasil}

Hasil merupakan tujuan dari didirikannya sebuah perusahaan. Namun, sebelum hasil tersebut di capai terlebih dahulu harus melalui sebuah proses, dari sebuah proses inilah kita bisa tau seperti apa hasil yang kita dapat, jika proses tersebut di lakukan dengan baik maka hasilnya akan baik juga. Namun, sebaliknya jika proses yang di lakukan tidak sempurna maka hasilnya juga tidak baik.

2. Berpikir secara sistematis pada seluruh proses 
Berpikir secara sistematis berarti proses yang sudah di lakukan telah memenuhi syarat dan standar ketentuan dari perusahan/organisasi itu sendiri.

3. Tidak menyalahkan, namun harus belajar dari kesalahan

Jika seorang karyawan melakukan kesalahan, pemimpin tidak perlu menyalahkan tapi harus memberikan arahan dan bimbingan dan karyawan yang lain harus belajar dari kesalahan tersebut.

\section{Kunci Pelaksanaan Kaizen}

Ada beberapa kunci dalam pelaksanaan kaizen yaitu :

1. Menghasilkan produksi dengan ketetapan jadwal dari pelanggan

Tujuan lain dari sebuah perusahaan adalah kepuasan pelanggan, jadi permintaan pelanggan harus di prioritaskan dan di wujudkan meski pelanggan menetapkan jadwal. Dari situlah pelanggan bisa memberikan ulasannya tentang pelayanan yang di dapat.

2. Memproduksi dalam jumlah kecil

Dalam memproduksi sebuah barang, perusahaan harus bisa memprediksi tentang peminat dari barang yang di produksi. Jika tidak hanya akan ada pemborosan dalan pebiayaan produksi dan pemborosan waktu dari proses produksi

3. Menghilangkan pemborosan

yaitu membatasi jumlah produksi,mengurangi biaya produksi, memperbaiki penanganan bahan baku,menyimpan persediaan dalam skala kecil, mencari dan mendapatkan pemasok yang dapat di percaya .

\section{Memperbaiki aliran produksi}

Berarti barang yang di produksi haruslah tembus ke pasaran

\section{Menyempurnakan kualitas produk}

yaitu melakukan pengendalian proses dan membuat semua pekerja merasa punya tanggungjawab terhadap tercapainya mutu, meningkatkan fungsi manajemen terhadap mutu, tmemenuhi pengendalian mutu produk dengan tegas, memberikan hak kepada karyawan untuk melakukan pengendalian mutu produk, melakukan pengecekan terhadap cacat produk oleh karyawan, tercapainya inpeksi $100 \%$ terhadap mutu produk dan tercapainya komitmen terhadap pengedalian mutu jangka panjang.

6. Orang-orang yang tanggap

yaitu seluruh karyawan harus mampu menguasi seluruh bidang dalam sesuai dengan pengetahuan, kemampuan dan kedudukannya.

7. Menghilangkan ketidakpastian 
yaitu menjaga hubungan yang erat dan memilki satu pemasok yang lokasinya dekat dengan perusahaan dan masih memiliki hubungan kerabat dengan pemimpin perusahaan.

8. Penekanan pada pemeliharaan jangka panjang

Jika suatu produk di hasilkan dengan baik maka pemeliharaan jangka panjang perlu di lakukan demi mempertahankan kualitas produk tersebut .

\section{Segmentasi Kaizen}

Segemen kaizen di bagi menjadi tiga, tegantung pada kebutuhan masing-masing perusahaan :

1. Berorientasi pada manajemen, yaitu memfokuskan pada masalah penyediaan bahan dan untuk mencapai kemajuan dan moral.

2. Berorientasi pada kelompok yang di lakukan oleh kelompok pengendali mutu, yaitu membentuk kelomok manajemen sukarela dengan menggunakan bilangan untuk menyelesaikan suatu masalah, menylidiki, menjalankan dan memutuskan prosedur baru.

3. Berorientasi pada individu, yaitu di wujudkan dalam bentuk saran yang mana seseorang harus bekerja lebih pintar jika tidak mau bekerja keras.

\section{Prinsip Kaizen}

Kaizen memiliki sepuluh prinsip :

1. Fokus pada pelanggan merupakan tujuan utama dari kaizen, namun, tujuan yang terpenting dari kaizen ialah kualitas produk. Tetapi, jika produksi tersebut tidak menambah nilai kualitas produk ataupun tidak meningkatkan kepuasan pada pelanggan maka hal itu merupakan suatu pemborosan.

2. Mengadakan peningkatan secara terus menerus, keberhasilan bukanlah hasil akhir melainkan awal untuk melangkah ke tahap berikutnya karena keberhasilan merupakan faktor pendukung untuk mencapai keberhasilan yang lain.

3. Mengakui masalah secara terbuka, suatu masalah dapat di selesaikan jika karyawan bersikap terbuka dengan masalah yang di hadapi.

4. Mempromosikan Keterbukaan Ilmu pengetahuan untuk berbagi pengetahuan dan hubungan komunikasi yang mendukungnya.

5. Menciptakan Tim Kerja, tim merupakan karyawan yang dibentuk dalam struktur organisasi, dengan memebentuk tim perusahaan akan mendapatkan keuntungan diman para karyawan akan merasa memiliki tanggung jawab bersama, dan berorientasi untuk kemajuan dan perkembangan perusahaan

6. Memanajemen Proyek Melalui Tim Fungsional-silang, perencanaan Proyek perusahaan dijalankan dengan memakai sumberdaya antar-departemen serta sumber daya yang berasal 
dari luar perusahaan. Kegiatan tersebut dilakukan dalam rangka meminimalkan biaya, mengecek pemborosan sampai level tertentu dan memberikan kepuasan pada pelanggan.

7. Memelihara Proses Hubungan yang Benar, hubungan sesama karyawan, pemimpin dengan bawahan memang harus di pelihara dengan baik agar tercipta keharmonisan dan menumbuhkan loyalitas serta komitmen karyawan.

8. Mengembangkan disiplin pribadi, kedisiplinan merupakan hal wajib di miliki oleh semua orang, dengan disiplin akan menunjang keberhasilan dalam melakukan segala aktivitas.

9. Menginformasikan kepada seluruh Karyawan, informasi merupakan hal penting dalam sebuah perusahaan, Dengan menginformasikan hal penting pada seluruh karyawan maka akan memberikan tantangan yang mulanya dari perusahaa menjadi tantangan pribadi. Memberikan informasi juga merupakan langkah penting dalam menciptakan budaya Yng didasarkan dari pengetahuan.

10. Memberikan hak pada seluruh pekerja dalam pelaksanaan kaizen, dalam hal ini karyawan dituntut untuk melakukan perubahan yang positif.

\section{Konsep Penting Kaizen}

Ada beberapa konsep penting dalam proses kaizen :

1. Konsep tiga M dalam istilah jepang yaitu : Muda, Mura, dan Muri. Konsep ini dibentuk dengan tujuan untuk mengurangi biaya dan mempersingkat waktu , mengurangi kelelahan, meningkatkan mutu.

a). Muda artinya mengurangi pemborosan

Pemborosan hanya akan menimbulkan dampak negatif, selain menyebabkan kerugian juga menyebabkan tenaga pekerja hilang sia-sia.

b). Mura artinya mengurangi perbedaan

Perbedaan juga bisa berdampak negatif di antaranya, ketidak harmonisannya hubungan sesama pekerja yang berdampak kepada perusahaan. Maka dari itu konsep ini menekankan untuk mengurangi perbedaan sehingga sesama pekerja bisa bersikap terbuka dan menjalin hubungan erat antar sesama pekerja.

c). Muri artinya mengurangi ketegangan

Saat para staff karyawan mengadakan rapat, dapat di pastikan ada ketegangan saat memberikan pendapatnya masing-masing.

2. Konsep gerakan 5S yaitu : Seiri, Seiton, Seiso, Seiketsu, dan Shitsuke.

a). Seiri berarti merapikan kantor

Konsep ini menjelaskan pada kita bahwa kebersihan perlu di lakukan demi terciptanya tempat kerja yang aman dan nyaman. 
b). Seiton artinya menyimpan dengan teratur

Pada konsep ini di maksudkan untuk tidak semena-mena menaruh barang-barang yang ada di sebuah perusahaan agar kita mudah mencari dan mengambilnya.

c). Seiso artinya menjaga kantor agar tetap bersih

Menjaga kebersihan di maksudkan tidak hanya petugas kebersihan saja yang harus menjaga kebersihan kantor tetapi semua karyawan juga harus menjaga kebersihan kantor d). Seiketsu artinya kebersihan pribadi

Sebelum menjaga kebersihan kantor seorang karyawan harus menjaga kebersihan diri terlebih dahulu di maksudkan sebagai cerminan ketika bekerja.

e). Shitsuke artinya disiplin

Disiplin merupakan cerminan dari pekerja yang baik, teratur, dan jujur sebagai langkah untuk menuju kesuksesan

3. Konsep PDCA (Plan, Do, Check, Action). Ketika ada tujuan yang ingin di capai dengan maksimal maka, perlu di lakukan dengan prosedur yang benar. Maka dari itu konsep ini perlu di lakukan secara terus menerus

4. Konsep 5W1H. Salah satu alat pola pikir untuk menjalankan konsep PDCA adalah dengan tehnik bertanya dengan pertanyaan $5 \mathrm{~W}+1 \mathrm{H}$

5. Konsep 5M (Man, Machine, Material, Methods, Measurement)

a). Man (orang)

b). Machine (mesin)

c). Material (material)

d). Methods (metode)

e). Measurement (pengukuran)

\section{Siklus PDCA}

Siklus PDCA merupakan prinsip dasar untuk melakukan perbaikan berkelanjutan yang penjelasannya sebagai berikut :

1. Planning, yang berarti merencanakan sesuatu yang ingin di capai, memahami apa yang ingin di capai, memahami permasalahan dan memecahkan akar permasalahannya, menciptakan solusi kreatif.

2. Do, yang berarti melakukan apa yang sudah di rencanakan, namun tidak mudah yang di bayangkan, biasanya ada masalah yang besar dan sering berubah pada saat-saat terakhir. Jika sudah seperti itu maka tidak bisa di lanjutkan lagi dan harus di mulai dari awal.

3. Chacking, yang berarti mengecek hasil yang di dapat dan membandingkannya sesuai dengan yang di inginkan. Jika segala sesuatu menjadi buruk dan hasil baik tidak di temukan. 
Maka, keberanian, kejujuran dan kecerdasan sangat di butuhkan untuk mengendalikan sebuah proses.

4. Action, yang berarti menindak lanjuti dari apa yang di dapat selama pengecekan. Dalam arti lain adalah mencapai tujuan dan menstandarisasikan proses atau belajar dari pengalaman untuk memulai lagi pada kondisi yang tepat.

\section{Perbedaan pendekatan perbaikan tradisional dan TQM}

\begin{tabular}{|c|c|c|}
\hline Aspek & Pendekatan Tradisional & $\begin{array}{l}\text { Pendekatan } \\
\text { TQM }\end{array}$ \\
\hline Alasan & $\begin{array}{l}\text { Perbaikan terjadi apabila } \\
\text { ada pengembangan } \\
\text { produk baru \& reaksi thd } \\
\text { masalah2 yang menonjol. }\end{array}$ & $\begin{array}{c}\text { Perbaikan } \\
\text { terjadi pada } \\
\text { setiap } \\
\text { kesempatan \& } \\
\text { bahkan pada } \\
\text { saat tidak ada } \\
\text { masalah besar. }\end{array}$ \\
\hline $\begin{array}{c}\text { Pendeka } \\
\text { tan }\end{array}$ & $\begin{array}{c}\text { Coba-coba } \\
\text { Trial and error }\end{array}$ & $\begin{array}{l}\text { Karya Ilmiah } \\
\text { Metode ilmiah }\end{array}$ \\
\hline $\begin{array}{c}\text { Respon } \\
\text { kesalaha } \\
\mathbf{n}\end{array}$ & $\begin{array}{c}\text { Tidaktoleran terhadap } \\
\text { kesalahan. } \\
\text { Hukuman, ketakutan, } \\
\text { menyembunyikan, } \\
\text { karyawan yg } \\
\text { bertanggungjawab }\end{array}$ & $\begin{array}{l}\text { Memandang } \\
\text { kesalahan } \\
\text { sebagai } \\
\text { kesempatan } \\
\text { belajar. } \\
\text { Pembelajaran, } \\
\text { keterbukaan, } \\
\text { berusaha } \\
\text { melakukan } \\
\text { perbaikan } \\
\text { proses, } \\
\text { manajemen } \\
\text { yang } \\
\text { bertanggung } \\
\text { jawab }\end{array}$ \\
\hline $\begin{array}{c}\text { Peran } \\
\text { manager }\end{array}$ & $\begin{array}{c}\text { Mengadministrasikan } \\
\text { sistem yang ada \& } \\
\text { memelihara. }\end{array}$ & $\begin{array}{l}\text { Melakukan } \\
\text { perbaikan } \\
\text { strategi. }\end{array}$ \\
\hline $\begin{array}{c}\text { Wewena } \\
\text { ng }\end{array}$ & $\begin{array}{c}\text { Membagi wewenang dari } \\
\text { ats ke bawah melalui } \\
\text { peraturan \& kebijakan. }\end{array}$ & $\begin{array}{c}\text { Masih } \\
\text { memegang tp } \\
\text { mengkomunikas } \\
\text { ikan \& } \\
\text { memberdayakan } \\
\text { anggota. }\end{array}$ \\
\hline Fokus & $\begin{array}{l}\text { Perbaikan hasil bisnis } \\
\text { melalui penentuan kuota } \\
\text { \& target. }\end{array}$ & $\begin{array}{c}\text { Hasil bisnis } \\
\text { melalui } \\
\text { kemampuan } \\
\text { sistem, alat } \\
\text { yang dikaitkan } \\
\text { dengan hasil. }\end{array}$ \\
\hline Control & $\begin{array}{c}\text { Pencatatan skor, } \\
\text { pelaporan, } \\
\text { pengevaluasian. }\end{array}$ & $\begin{array}{c}\text { Belajar } \\
\text { statistika } \\
\text { mengenai } \\
\text { variasi } \\
\text { penyebab. }\end{array}$ \\
\hline Alat & $\begin{array}{l}\text { Mendelegasikan pada } \\
\text { staf atau bawahan }\end{array}$ & $\begin{array}{c}\text { Dimiliki } \\
\text { manajer \& } \\
\text { dilakukan oleh } \\
\text { staf atau } \\
\text { bawahan. }\end{array}$ \\
\hline
\end{tabular}

\section{Identifikasi kebutuhan akan perbaikan}


Dalam organisasi hanya memiliki sumber daya yang sedikit dan terbatas sehingga harus dioptimalkan agar menghasilkan manfaat yang maksimal. Ada beberapa strategi yang bisa di terapkan untuk mengidentifikasi kebutuhan akan perbaikan, yaitu :

1. Menerapkan multi-voting

2. Mengidentifikasi kebutuhan pelanggan

Kebutuhan pelanggan memang harus di utamakan. Untuk itu identifikasi kebutuhan pelanggan sangat perlu di lakukan supaya bisa tahu apa yang sangat di butuhkan oleh pelanggan.

3. mempelajari penggunaan waktu

Penggunaan waktu pada sebuah perusahaan haruslah efektif agar terhindar dari pemborosan. Jadi, mempelajari penggunaan waktu mremang perlu di lakukan.

4. Mengalokasikan masalah

Masalah bisa datang kapan saja tanpa di sadari, oleh sebab itu pentinglah untuk memprediksi masalah apa yang akn terjadi dan menentukan langkah apa yang tepat untuk mencegah masalah itu muncul.

\begin{tabular}{|l|l|}
\hline \multicolumn{1}{|c|}{ KAIZEN } & \multicolumn{1}{|c|}{ INOVASI } \\
\hline $\begin{array}{l}\text { Orientasi Umum } \\
\text { Orientasi pada Manusia } \\
\text { Perhatian pada }\end{array}$ & $\begin{array}{l}\text { Orientasi pada } \\
\text { Keahlian } \\
\text { Pendalaman }\end{array}$ \\
$\begin{array}{l}\text { Orientasi pada } \\
\text { Dibangun dengan Teknologi }\end{array}$ & Perhatian Lompatan \\
Informasi terbuka, & Jauh \\
dibagikan & Cari Teknologi Baru \\
Kelompok Kerja & Informasi tertutup \\
& Perorangan \\
& -Individual \\
\hline
\end{tabular}

\section{Perbedaan Kaizen dan Inovasi}

Aspek terpenting dari kaizen adalah mengutamakan proses, hal ini berlawanan dengan manajemen barat yang menilai bahwa performa karyawan hanya atas dasar hasil yang di perolehnya dan bukan karena usaha mereka. Dibawah ini akan menjelaskan tentang perbedaan antara kaizen dengan inovasi berdasarkan karakteristiknya :

\section{Penutup}

Kaizen merupakan filosofi jepang yang memfokuskan pada pengembangan dan penyempurnaan secara terus menerus dalam suatu perusahaan bisnis. Kaizen terdiri dari dua kata yaitu kai yang artinya perubahan dan zen yang artinya baik. Dalam istilah lain, kaizen disebut juga sebagai continous improvement yang berarti perbaikan secara terus menerus. Jadi, kaizen adalah usaha secara terus menerus untuk memperbaiki suatu proses yang ada pada sebuah perusahaan. 
Kaizen mempunyai prinsip-prinsip sebagai berikut:a) Fokus kepada pelanggan, Fokus utama kaizen adalah kualitas produk, tetapi tujuan terpenting kaizen adalah kepuasan pelanggan. b) Mengadakan Peningkatan Terus Menerus Dalam kaizen. c) Mengakui Masalah Secara Terbuka. d) Mempromosikan Keterbukaan Ilmu pengetahuan. e) Menciptakan Tim Kerja. f) Memanajemen Proyek Melalui Tim Fungsional-silang. g) Memelihara Proses Hubungan yang Benar. h) Mengembangkan disiplin pribadi. i) Memberikan Informasi pada Semua Karyawan. j) Memberikan Wewenang Kepada Setiap Karyawan Dalam pelaksanaan kaizen.

Beberapa point penting dalam proses penerapan Kaizen yaitu: a). Konsep 3M (Muda, Mura, dan Muri). b) Gerakkan 5S (Seiri, Seiton, Seiso, Seiketsu dan Shitsuke) atau 5R. c) Konsep PDCA dalam Kaizen. d) Konsep 5W + 1H ( What, Who, Why, Where, When dan How). e) Konsep 5M (Man, Machine, Material, Methods, Measurement).

Kaizen identik dengan siklus rencana-kerjakan-periksa-tindakan (Plan, Do, Check, Act atau PDCA). PDCA adalah prinsip dasar untuk perbaikan secara terus menerus.

Ada empat strategi yang dapat diterapkan untuk mengidentifikasi kebutuhan akan perbaikan, yaitu: a). menerapkan multi-voting. b) mengidentifikasi kebutuhan pelanggan. c)mempelajari pengunaan waktu. d) mengalokasikan masalah.

\section{DAFTAR PUSTAKA}

Bounds, G., et al. (1994). Beyond Total Quality management. New York: McGraw-Hill, Inc.

Hariyadi. 2009. Pelatihan Penerapan standar internasional berbasis Quality Management System. Penerbit Nusantara Professional Education. Jakarta

Hardjosoedarmo, Soewarso. 2004. Total Quality Management. Penerbit Andi Yogyakarta.

Imai, Masaaki. 1998. Kaizen: Pendekatan Akal Sehat, Berbiaya Rendah pada Manajemen. Jakarta: CV Taruna Grafica

Imai, Masaaki. 2005. Kaizen. Jakarta: PT Pustaka Binaman Pressindo

Handayani, Ratna (2005). Nilai Pemikiran Suzuki Shosan dan Ishida Baigan dalam Gemba Kaizen sebagai Pendekatan Akal Sehat, berbiaya Rendah pada Manajemen Jepang. Jurnal Nihon Gakushuu, 1.

Hirano, Hiroyuki. (2005). Penerapan 5S di Tempat Kerja. Jakarta: PQM

Monden, Yasuhiro. (1995). Sistem Produksi Toyota: Suatu Ancangan Terpadu untuk

Penerapan Just in Time (buku pertama).Jakarta: PT Pustaka Binaman Pressindo. 
